\title{
Morphometric characterization of Dinophysis acuminata/D. sacculus complex in Guanabara Bay, Brazil
}

\author{
José Juan Barrera-Alba ${ }^{I}$, Fernanda Reinhardt Piedras ${ }^{2}$, Carla Lucatelli Duarte ${ }^{I}$, Raquel Neves Tavares \\ Lopes $^{2}$ \& Gleyci Aparecida Oliveira Moser ${ }^{2} *$ (i) \\ ${ }^{1}$ Universidade Federal de São Paulo, Departamento de Ciências do Mar, Campus Baixada Santista, Santos, SP, \\ Brasil \\ ${ }^{2}$ Universidade do Estado do Rio de Janeiro, Faculdade de Oceanografia, Departamento de Oceanografia \\ Biológica, Rio de Janeiro, RJ, Brasil \\ *Corresponding author: Gleyci Aparecida Oliveira Moser,e-mail: gleycimoser@gmail.com
}

BARRERA-ALBA, J.J., PIEDRAS, F.R., DUARTE, C.L, LOPES, R.N.T, MOSER, G.A.O. Morphometric characterization of Dinophysis acuminata/D. sacculus complex in Guanabara Bay, Brazil. Biota Neotropica. 19(3): e20180607. http://dx.doi.org/10.1590/1676-0611-BN-2018-0607

\begin{abstract}
Most studies of Dinophysis acuminata in Brazil are for the southern region, where blooms are recurrent. In 2016, the presence of $D$. acuminata caused the first-ever production and consumption of species of mollusks commercial embargo from the state of Sao Paulo, Southeast Brazil. Potentially toxic species of Dinophysis have been reported in Guanabara Bay (GB) but only occasionally and in low densities. The present note is the first report of a high-density event $\left(\sim 10^{5}\right.$ cells $\left.\mathrm{L}^{-1}\right)$ of $D$. acuminata/D. sacculus complex in GB. D. acuminata/D. sacculus complex species were identified using scanning-electron and inverted-light microscopy. Most of the studied cells possessed a dorsally convex hyposomal plate and had dimensions typical of $D$. acuminata. However, the observed association with warmer and less saline estuarine waters would indicate that the species could be D. sacculus. Whatever the case, based on the high cell densities observed here, we recommend a continued monitoring for Dinophysis presence in GB.

Keywords: dinoflagellates, Dinophysis acuminata, Dinophysis sacculus, eutrophic marine ecosystem, South Atlantic Central Water
\end{abstract}

\section{Caracterização morfométrica de dinoflagelados do Complexo Dinophysis acuminata/D. saculus na Baía de Guanabara, Brasil}

\begin{abstract}
Resumo: A maioria dos estudos sobre Dinophysis acuminata no Brasil ocorreram na região sul, onde as florações são recorrentes. Em 2016, a presença de D. acuminata causou o primeiro embargo comercial da produção e consumo de espécies de moluscos do estado de São Paulo, sudeste do Brasil. Várias espécies de microalgas potencialmente nocivas foram relatadas na Baía de Guanabara (BG), incluindo espécies tóxicas de Dinophysis, mas estas foram reportadas apenas como ocasionais e em baixas densidades. A presente nota é o primeiro relato de um evento de alta densidade $\left(\sim 10^{5}\right.$ células $\left.\mathrm{L}^{-1}\right)$ do complexo D. acuminata/D. saculus na BG. As espécies foram identificadas através de microscopia eletrônica de varredura e de campo claro. A maioria das células estudadas possuía uma placa hipossômica dorsalmente convexa, e tinha dimensões típicas de D. acuminata. No entanto, a associação observada com águas estuarinas mais quentes e menos salinas indicaria que a espécie seria $D$. saculus. Qualquer que seja o caso, com base nas altas densidades observadas aqui, recomendamos o monitoramento contínuo da presença de Dinophysis na BG.

Palavras-chave: dinoflagelados, Dinophysis acuminata, Dinophysis saculus, ecossistema marinho eutrófico, Água Central do Atlântico Sul.
\end{abstract}




\section{Introduction}

The genus Dinophysis Ehrenberg includes species with a diverse morphology and different trophic strategies (autotrophic, heterotrophic and mixotrophic) (Zingone et al. 1998). Some of these species are potential producers of phytotoxin and can be responsible for human intoxication events, even in densities as low as $<10^{2}$ cells $\cdot \mathrm{L}^{-1}$, which are rarely detected by quantitative methods (Reguera et al. 2012). Dinophysis acuminata Claparède \& Lachmann (Hattenrath-Lehmann et al. 2015) has received significant attention because inputs of nutrients and organic matter can promote both its toxicity and growth. Nevertheless, this species belongs to the " $D$. acuminata complex", which contains taxa that are difficult to discriminate with conventional microscopy due to morphological variability (Reguera et al. 2012). One such case is the pair D. acuminata Claparède \& Lachmann/D. sacculus F. Stein (Zingone et al. 1998), which can co-occur (Reguera et al. 2012). Both species have been associated with diarrhetic shellfish poisoning (DSP) events (Reguera et al. 2012, and references, García-Altares et al. 2016).

In Brazil, most of the studies on D. acuminata have occurred in the South region, due to its great importance for oyster and mussel cultivation. (Mafra-Junior et al. 2006, Mello et al. 2010, Simões et al. 2014, Tibiriçá et al. 2015). Natural blooms of this species along the southern Brazilian coast lead to recurrent commercial embargos of cultivated species, resulting in important economic losses (Simões et al. 2014). From May to July 2016, D. acuminata was reported along the coast from Santa Catarina to São Paulo in densities that led to the first-ever commercial embargo of the production and consumption of oysters and mussels by the health authorities of the state of São Paulo (A Tribuna 2016).

Although D. acuminata has been detected along Rio de Janeiro's coast, blooms have not been reported yet. At Sepetiba Bay on the southern coast of Rio de Janeiro, D. acuminata was found to be dominant among the five species of the genus detected, but both cell densities and toxin concentrations on mussels were lower than the limit allowed by law (Ferreira et al. 2010, Brasil 2012). Guanabara Bay (GB) encompasses many more municipalities than the city of Rio de Janeiro, being the second largest bay of the Brazilian coast, and is historically under intense eutrophication, thus a program of continuous monitoring of planktonic species should be implemented (Fistarol et al. 2015). Several potentially harmful microalgal species have been reported at high densities in GB: Scrippsiella trochoidea (Stein) Loeblich (Villac \& Tenenbaum 2010), Pseudo-nitzschia H. Peragallo spp. (Rezende et al. 2015), filamentous cyanobacteria, Prorocentrum Ehrenberg spp. (Villac \& Tenenbaum, 2010, Rezende et al. 2015), and Chattonella B.Biecheler spp. (Fistarol et al. 2015). The potentially toxic species of the genus Dinophysis (i.e. D. acuminata/D. sacculus), however, have been described as only occasional and in low densities (Rezende et al. 2015). Nonetheless, several studies have recommended the implementation of protocols able to detect Dinophysis sp. at low-densities $\left(<10^{2}\right.$ cells $\left.\mathrm{L}^{-1}\right)$ in the water column serving as an early warning system (Reguera et al. 2014).

The present work is the first report of a bloom of Dinophysis in Guanabara Bay, Rio de Janeiro (Brazil), and a morphological and morphometric study of the analyzed cells is provided.

\section{Material and Methods}

Surveys were performed on September $1^{\text {st }}, 2015$, along a transect of eight sampling points from Paquetá Island (inner region) to Rasa Island (outer region) along the dredged channel of Guanabara Bay (22 $\left.{ }^{\circ} 80^{\prime} \mathrm{S} ; 4^{\circ} 14^{\prime} \mathrm{W}\right)$ (Figure 1). Phytoplankton samples were collected, both during ebb and during flood tides, with Niskin bottles at subsurface and near the bottom. Sub-samples of $250 \mathrm{~mL}$ were fixed with Lugol's solution and preserved in the dark, at room temperature, until laboratory analysis. At laboratory, aliquots of $5-10 \mathrm{~mL}$ were prepared according to the Utermölh (1958) method and examined and photographed under $200 \mathrm{x}$ and $400 \mathrm{x}$ magnification using a ZEISS ${ }^{\circledR}$ Axiovert A1 inverted microscope and an ZEISS ${ }^{\circledR}$ AxioCAM 105 camera. Bright field (BF) and phase contrast (PH) were used for identification. Images of the different organisms identified were captured with the AxioCAM 105 camera and processed with the software Zen (Blue Edition; Carl ZEISS $\left.{ }^{\circledR}\right)$. The images of 55 organisms were used to measure the morphological parameters (length, width and the hidden dimension) of the cells of $D$. acuminata/D. sacculus complex. Cell surface and cell volume were calculated according with the equations described in Sun \& Liu (2003). Samples were prepared for scanning electron microscopy (SEM) by gentle filtration of $20 \mathrm{ml}$ through 0.2 $\mu \mathrm{m}$ pore-size Nuclepore membranes. Salt was removed by washing the filters with small amounts of deionized water. The filters were dried, mounted on stubs with double-sided sticky tape and vacuum coated with graphite. The samples were examined with a JEOL JSM 6510LV scanning electron microscope.

The relationships among phytoplanktonic cell densities and abiotic variables were determined using Pearson's correlation (Software Statistica ${ }^{\circledR}$ by Statsoft) (Cassie, 1962).

\section{Results}

Water temperature was higher in the inner region $\left(19.9-25.1^{\circ} \mathrm{C}\right)$ than in the outer region $\left(16.1-19.8^{\circ} \mathrm{C}\right)$ of the bay. Salinity ranged from 24.2 to 35.2 in the inner region, and from 35.3 to 36.0 in the outer. Total chlorophyll ranged from 2.04 to $45.03 \mathrm{mg} \mathrm{m}^{-3}$ in the inner region, and from 0.45 to $7.48 \mathrm{mg} \mathrm{m}^{-3}$ in the outer.

Phytoplankton densities were higher in the inner region $\left(2.8 \times 10^{5}-\right.$ $2.8 \times 10^{7}$ cells $\left.\mathrm{L}^{-1}\right)$ than in the outer region $\left(5.1 \times 10^{3}-4.1 \times 10^{6}\right.$ cells $\left.\mathrm{L}^{-1}\right)$. Although they were not dominant, dinoflagellate densities ranged from $1.3 \times 10^{4}-2.2 \times 10^{6}$ cells $\mathrm{L}^{-1}$ to $4.0 \times 10^{1}-3.9 \times 10^{5}$ cells $\mathrm{L}^{-1}$, in the inner and outer regions, respectively. Among the dinoflagellates, the genus Prorocentum was dominant (average $>50 \%$ ), both in the inner and outer regions. The contribution of the genus Dinophysis was lower than $10 \%$ on average (maximum $25 \%$ ), with the $D$. acuminata/D. sacculus complex being dominant for this genus (maximum $1.2 \times 10^{5}$ cells $\mathrm{L}^{-1}$ at inner portion) (Table 1). The cell density of the D. acuminata/D. sacculus complex was positively correlated with that of $P$. dentatum $(\mathrm{r}=0.91 ; \mathrm{p}<0.001)$ and $P$. micans $(\mathrm{r}=0.79 ; \mathrm{p}<0.01)$. The abundance of D. acuminata/D. sacculus complex was also positively correlated $(\mathrm{r}=$ $0.72 ; \mathrm{p}<0.001)$ with temperature and negatively correlated $(\mathrm{r}=-0.61$; $\mathrm{p}<0.001$ ) with salinity. 


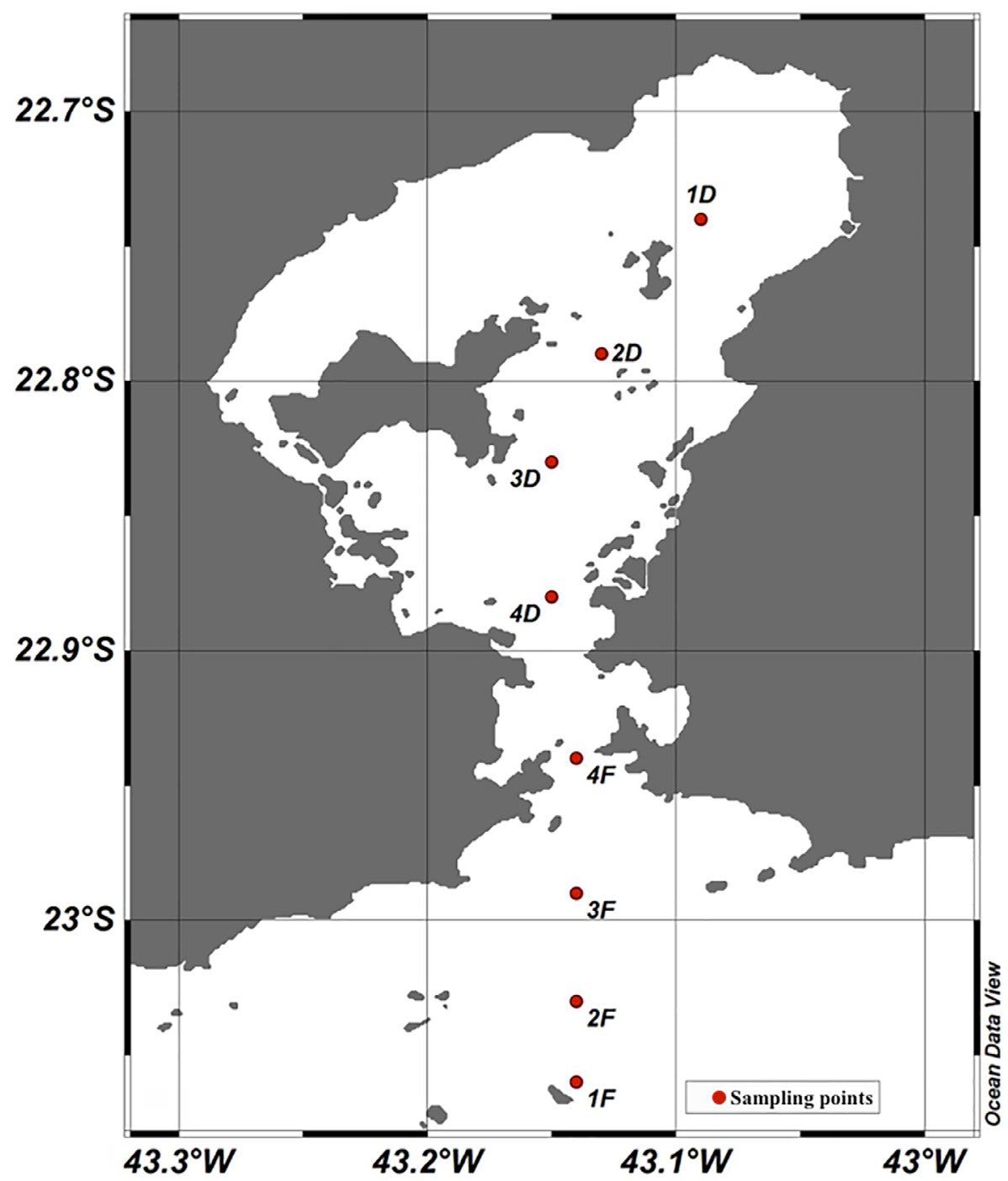

Figure 1. Study area - Guanabara Bay (Rio de Janeiro, Brazil). Sampling points (red dots) in a transect from the inner part of the bay (denoted by a number and letter D) to the inner continental shelf (denoted by a number and letter F).

Table 1. Average (av.), standard deviation (sd), minimum (min) and maximum (max) of cell densities $\left(\times 10^{3}\right.$ cells $\left.\mathrm{L}^{-1}\right)$ of Dinophysis genera, Dinophysis acuminata/sacculus complex, and Prorocentrum genera at inner and outer regions.

\begin{tabular}{lcccc}
\hline Region & & $\begin{array}{c}\text { Dinophysis } \\
\text { acuminata/ } \\
\text { sacculus complex }\end{array}$ & $\begin{array}{c}\text { Prorocentrum } \\
\text { micans }\end{array}$ & $\begin{array}{c}\text { Prorocentrum } \\
\text { dentatum }\end{array}$ \\
\hline \multirow{4}{*}{ inner } & av. & 22.57 & 210.84 & 339.73 \\
& sd & 29.34 & 332.52 & 330.74 \\
& $\min$ & 1.40 & 0.40 & 3.40 \\
& max & 115.55 & 1021.91 & 837.75 \\
& av. & 0.77 & 5.17 & 10.48 \\
& sd & 0.97 & 12.51 & 16.07 \\
& $\min$ & 0.00 & 0.00 & 0.00 \\
& $\max$ & 3.00 & 43.00 & 50.20 \\
\hline
\end{tabular}

Cells of the Dinophysis acumitata/D. sacculus complex were $33.2-44.2 \mu \mathrm{m}$ long, $20.3-32.3 \mu \mathrm{m}$ wide, and $13.5-20.1 \mu \mathrm{m}$ of hidden dimension (Table 2$)$. The length/width $(1 / \mathrm{w})$ ratio varied from 1.2 to 1.9 and the Surface/Volume ratio ranged from 0.24 to 0.28 . The shape of the cells was slightly convex, with a convex and sculptured sulcal platelet with three ribs, which was almost half of the hypothecal length (Figure 2a-g); this morphotype is intermediate between the two species of this complex.

Under SEM, small smooth pores were seen irregularly scattered on the surface of the hypotheca (Figure 2a). The number of pores distributed along $10 \mu \mathrm{m}$ varies from six in the middle region of the hypotheca, to 12 near the cingular platelet (Figure $3 \mathrm{a}-\mathrm{b}$ ). Two rows of pores were observed on the sulcal platelet (Figure 3c). 
Table 2. Average (av.), standard deviation (sd, minimum (min) and maximum (max) length, width, hidden dimension, length/width $(1 / w)$ ratio, surface $(\mathrm{S})$, volume (V) and $\mathrm{S} / \mathrm{V}$ ratio for the Dinophysis acuminata/D. sacculus complex at September $2015(\mathrm{n}=55)$.

\begin{tabular}{lcccc}
\hline \multicolumn{4}{l}{ Dinophysis acuminata/D. sacculus complex metrics } \\
\hline & av. & sd & min & max \\
\hline length $(\mu \mathrm{m})$ & 38.8 & 1.9 & 33.2 & 44.2 \\
width $(\mu \mathrm{m})$ & 25.1 & 2.7 & 20.3 & 32.3 \\
hidden dimension $(\mu \mathrm{m})$ & 16.9 & 2.4 & 13.5 & 20.1 \\
l/w ratio & 1.56 & 0.14 & 1.17 & 1.90 \\
$\mathrm{~S}\left(\mu \mathrm{m}^{2}\right)$ & 2226 & 229 & 1709 & 2812 \\
$\mathrm{~V}\left(\mu \mathrm{m}^{3}\right)$ & 8648 & 1188 & 6085 & 11651 \\
$\mathrm{~S} / \mathrm{V}$ & 0.26 & 0.01 & 0.24 & 0.28 \\
\hline
\end{tabular}

\section{Discussion}

During the winter of 2015 , a high-abundance $\left(\sim 10^{5}-10^{6}\right.$ cells $\left.\mathrm{L}^{-1}\right)$ event of dinoflagellates was observed at Guanabara Bay (Rio de Janeiro, Brazil). It was dominated by the genus Prorocentrum Ehrenberg, mainly the species $P$. dentatum F.Stein and $P$. micans Ehrenberg. Associated with these, the high cell densities of the Dinophysis acuminata/D. sacculus complex were also observed. The co-occurrence of Dinophysis and Prorocentrum blooms were previously reported by several studies (i.e. Reguera et al. 2012, Hattenrath-Lehmann et al. 2015), as well as the occurrence of a bloom of Prorocentrum after Dinophysis events (Campbell et al. 2010). Prorocentrum micans, which reached densities as high as $10^{6}$ cells $\mathrm{L}^{-1}$ in the present work, was reported as highly abundant in warm and nutrient-rich waters, such as that of GB (Sahraoui et al. 2013). Prorocentrum micans was also reported as a producer of putative palytoxin and ovatoxin-a (Ignatiades \& Gotsis-Skretas 2010), nevertheless, the frequent association of this species with DSP could be due to the presence of $D$. acuminata in densities too low to be detected (Reguera et al. 2014 and references therein).

Although D. acuminata is usually associated with colder waters and $D$. sacculus with warmer waters, the two species were reported coexisting in several coastal environments, probably due to the difficulty in distinguishing their cells (Zingone et al. 1998). Thus, in GB, the Dinophysis complex was clearly associated with the warmer and less saline waters of the inner estuary. In a study in southern Brazil, Haraguchi and Odebrecht (2010) reported high abundances of D. acuminata $\left(\sim 10^{4}\right.$ cells $\left.\mathrm{L}^{-1}\right)$ associated with intrusions of a cold and salty water mass, the South Atlantic Central Water (SACW), while other species of Dinophysis, such as D. fortii Pavillard, were associated with warmer waters. In the present work, the influence of the SACW was especially observed in the outer region of GB (data not published), where lower densities of the D. acuminata/D. sacculus complex were observed, suggesting that most of the cells identified were probably D. sacculus.

Based on morphometric characteristics, most of the cells identified here possess a more dorsally-convex hypothecal plate with dimensions (especially the ratio $1 / \mathrm{w}$ ) typical of $D$. acuminata, and even the length of the cells found here is considerably shorter than those described in the

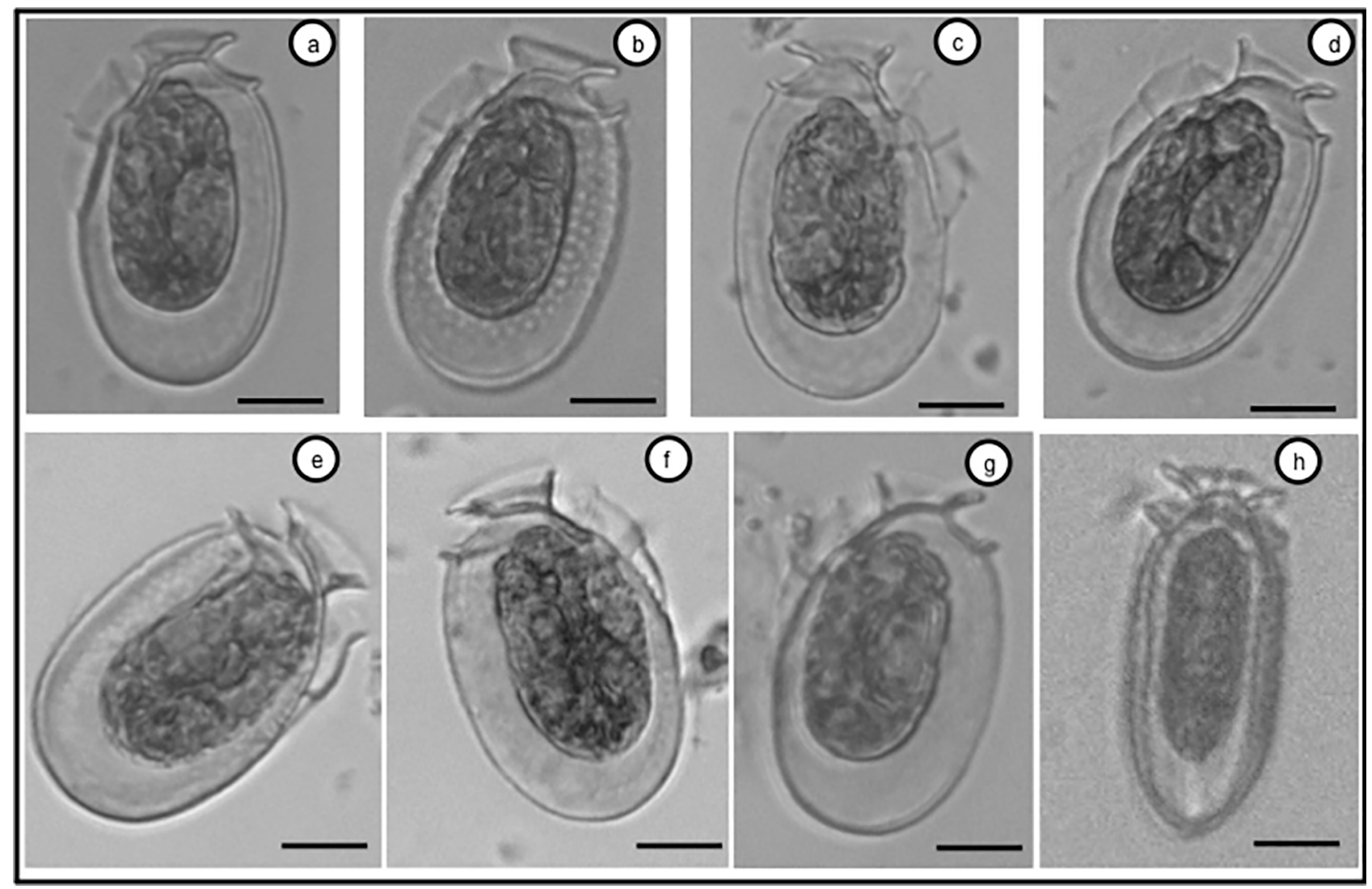

Figure 2. Lateral view (a-g) and hidden dimension (h) view of complete cells at Light Microscopy (LM) of Dinophysis acuminata/D. sacculus complex from Guanabara Bay samples. Scale bars: $10 \mu \mathrm{m}$. 


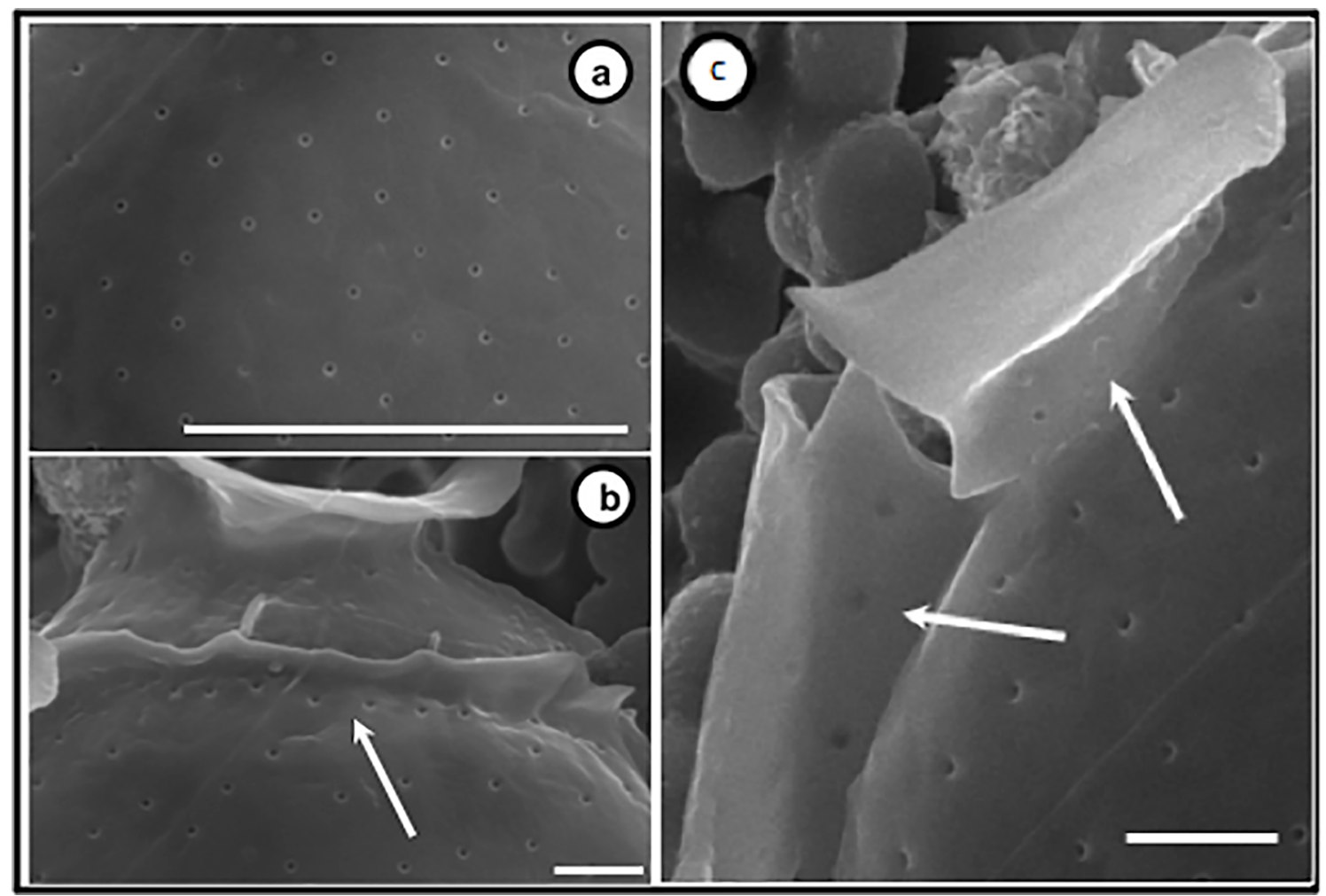

Figure 3. Details of the theca, scanning electron microscopy (SEM), of the cells of Dinophysis acuminata/D. sacculus complex from Guanabara Bay samples. Scale bars: a $10 \mu \mathrm{m}$; b-c $2 \mu \mathrm{m}$. Arrows indicate pores distribution.

literature (Zingone et al. 1998). On the other hand, the association with warmer and less saline estuarine waters was reported more often for $D$. sacculus than for $D$. acuminata, the latter being typical of colder waters. Nevertheless, both species of this complex were reported as potentially toxic even in low densities, as is the case for $D$ acuminata (Zingone et al. 1998, Reguera et al. 2012, Reguera et al. 2014). In addition, nutrient loading can enhance both growth and toxicity of Dinophysis species (Hattenrath-Lehmann et al. 2015).

Thus, even without the ability to distinguish between the two species of the D. acuminata/D. sacculus complex, high densities of this complex would be monitored in highly eutrophic coastal areas, such as Guanabara Bay.

\section{Acknowledgements}

We thank CAPES CIÊNCIAS DO MAR (No 43/2013) for their financial support and for providing scholarship; and the collaboration of Drs. Alexandre Macedo Fernandes and Ana Furtado.

\section{Conflicts of interest}

The authors declare that they have no conflict of interest related to the publication of this manuscript.

\section{Author Contributions}

José Juan Barrera-Alba: substantial contribution in the concept and design of the study, contributed also to data analyses and manuscript preparation.

Fernanda Reinhardt Piedras: substantial contribution in the concept and design of the study, contributed also to data analyses and manuscript preparation.

Gleyci Aparecida Oliveira Moser: substantial contribution in the concept and design of the study, contributed also to data analyses and manuscript preparation.

Carla Lucatelli Duarte: contributed to data analysis and interpretation.

Raquel Neves Tavares Lopes: contributed to data analysis and interpretation.

\section{References}

A Tribuna 2016. Consumo e venda de moluscos estão proibidos no Estado de São Paulo. http://www.atribuna.com.br/noticias/noticias-detalhe/santos/ consumo-de-moluscos-bivalves-estaproibido/?cHash=c936e644836340a5 b4c19ae8655eeacf. (last access 17/02/2017)

CAMPBELL, L., OLSO, R.J., SOSIK, H.M., ABRAHAM, A., HENRICHS, D.W., HYATT, C.J., \& BUSKEY, E.J. 2010. First harmful Dinophysis (Dinophyceae, Dinophysiales) bloom in the U.S. is revealed by automated imaging flow cytometry. J. Phycol. 46(1): 66-75. 
CASSIE, R.M. 1962. Frequency distribution models in the ecology of plankton and other organisms. J. Anim. Ecol. 31: 65-92.

FERREIRA V.M., OLIVEIRA G.M., PEREIRA M.M.D., SILVA, P.P.O., BORBA, H.R., LOURENÇO,A.J. \& SILVA, P.F.N. 2010. Produção da ficotoxina diarreica ácido ocadaico associada à microalga Dinophysis acuminata (Ehremberg 1839) na baía de Sepetiba, RJ e sua implicação para a saúde pública. R. Bras. Ci. Vet. 17(2): 87-90.

FISTAROL G.O.,COUTINHO F.H., MOREIRAA.P.B., VENAS, T., CANOVAS. A., PAULA, S.E.M., COUTINHO, R., MOURA, R.L.,VALENTIN, J.L., TENENBAUM, D.R., PARANHOS, R.,VALLE, R.A.B., VICENTE, A.C.P., AMADO, G., PEREIRA, R.C., KRUGER, R., REZENDE, C.E, THOMPSON, C.C., SALOMON, P. \& THOMPSON, F.L. 2015. Environmental and sanitary conditions of Guanabara Bay, Rio de Janeiro. Front. Microbiol. 6: 1-17.

GARCÍA-ALTARES, M., CASANOVA, A., FERNÁNDEZ-TEJEDOR, M., DIOGĖNE, J. \& DE LA IGLESIA, P. 2016. Bloom of Dinophysis spp. dominated by D. SACCULUS and its related diarrhetic shellfish poisoning (DSP) outbreak in Alfacs Bay (Catalonia, NW Mediterranean Sea): Identification of DSP toxins in phytoplankton, shellfish and passive samplers. Reg. Stud. Mar. Sci. 6: 19-28.

HARAGUCHI, L., and ODEBRECHT, C. 2010. Dinophysiales (Dinophyceae) no extremo Sul do Brasil (inverno de 2005, verão de 2007). Biota Neotrop. 10(3): 101-114. http://www.biotaneotropica.org.br/v10n3/en/ abstract?article+bn01910032010 (último acesso em 05/05/2019)

HATTENRATH-LEHMANN, T.K., MARCOVAL, M.A., MITTLESDORF, H., GOLESKI, J.A, WANG, Z., HAYNES, B., MORTON, S.L. \& GOBLER, C.J. 2015. Nitrogenous Nutrients Promote the Growth and Toxicity of Dinophysis acuminata during Estuarine Bloom Events. PLoS ONE 10(4):e0124148.

IGNATIADES, L. \& GOTSIS-SKRETAS, O. 2010. A Review on Toxic and Harmful Algae in Greek Coastal Waters (E. Mediterranean Sea). Toxins 2: $1019-1037$

MAFRA-JUNIOR, L.L., FERNANDES, L.F. \& PROENÇA, L.A.O. 2006. Harmful algae and toxins in Paranaguá Bay, Brazil: bases for monitoring. Braz. J. Oceanogr. 54(2-3): 107-121.

MELLO, D.F., PROENCA, L.A.O. \& BARRACCO, A.M. 2010. Comparative Study of Various Immune Parameters in Three Bivalve Species during a Natural Bloom of Dinophysis acuminata in Santa Catarina Island, Brazil. Toxins 2: 1166-1178.
REGUERA, B., VELO-SUÁREZ, L., RAINE, R. \& PARK, M.G. 2012. Harmful Dinophysis species: A review. Harmful Algae, 14, 87-106.

REGUERA, B., RIOBÓ, P., RODRÍGUEZ F., DÍAZ, P.A., PIZARRO, G., PAZ, B., FRANCO, J.M. \& BLANCO, J. 2014. Dinophysis toxins: Causative organisms, distribution and fate in shellfish. Mar. Drugs 12(1): 394-461.

REZENDE, K.R.V., HATHERLY, M.M.F., PIMENTA, C.M.M., EDUARDO, J., VIANNA, S.C. \& MANGIAVACCHI, N. 2015. Phytoplankton community structure in one sector of Guanabara Bay (RJ, Brazil) during 2011 and 2012. Braz. J. Oceanogr. 63(3): 239-254.

SAHRAOUI, I., BOUCHOUICHA, D., MABROUK, H.H. \& HLAILI, A.S. 2013. Driving factors of the potentially toxic and harmful species of Prorocentrum Ehrenberg in a semi-enclosed Mediterranean lagoon (Tunisia, SW Mediterranean). Mediterr. Mar. Sci. 14(2): 353-362.

SIMÕES, E., VIEIRA, R.C., SCHRAMM M.A., MELLO, D.F., PONTINHA, V.A., SILVA, P.M. \& BARRACCO, M.A. 2015. Impact of harmful algal blooms (Dinophysis acuminata) on the immune system of oysters and mussels from Santa Catarina, Brazil. J. Mar. Biol. Assoc. UK. 95(4): 773-781.

SUN, J. \& LIU, D. 2003. Geometric Models for Calculating Cell Biovolume and Surface Area for Phytoplankton. J. Plankton Res.. 25(11): 1331-1346.

TIBIRIÇÁ, C.E.J.A., FERNANDES, L.F. \& MAFRA-JUNIOR, L.L. 2015. Seasonal and spatial patterns of toxigenic species of Dinophysis and PseudoNitzschia in a subtropical Brazilian Estuary. Braz. J. Oceanogr. 63(1): 17-32.

UTERMÖHL H., 1958. Zur vervollkommnung der quantitativen phytoplanktonmethodik. Mitt. Int. Ver. Theor. Angew. Limnol. 9: 1-38.

VILLAC, M.C. and TENENBAUM, D.R. 2010. The phytoplankton of Guanabara Bay, Brazil. I. Historical account of its biodiversity. Biota Neotrop. 10(2): 271-293. http://www.biotaneotropica.org.br/v10n2/pt/ abstract?article+bn02410022010 ISSN 1676-0603 (último acesso em 05/05/2019)

ZINGONE, A., MONTRESOR, M. \& MARINO, D. 1998. Morphological variability of the potentially toxic dinoflagellate Dinophysis sacculus (Dinophyceae) and its taxonomic relationships with $D$. pavillardii and $D$. acuminata. Eur. J. Phycol. 33: 259-273.
Received: 07/01/2019 Revised: $21 / 05 / 2019$

Accepted: 23/05/2019

Published online: 01/07/2019 